\title{
BAG3 wt Allele
}

National Cancer Institute

\section{Source}

National Cancer Institute. BAG3 wt Allele. NCI Thesaurus. Code C105995.

Human BAG3 wild-type allele is located within 10q25.2-q26.2 and is approximately $26 \mathrm{~kb}$ in length. This allele, which encodes BAG family molecular chaperone regulator 3 protein, plays a role in the modulation of both apoptosis and protein folding. Mutation of the gene is associated with both myopathy myofibrillar type 6 and cardiomyopathy dilated type $1 \mathrm{HH}$. 